\title{
Enhancing policy delivery: normalizing four critical contributions
}

Article

Accepted Version

Kakabadse, A. P. and Kakabadse, N. ORCID:

https://orcid.org/0000-0002-9517-8279 (2021) Enhancing policy delivery: normalizing four critical contributions. British Politics. ISSN 1746-918X doi: https://doi.org/10.1057/s41293021-00161-z Available at https://centaur.reading.ac.uk/96459/

It is advisable to refer to the publisher's version if you intend to cite from the work. See Guidance on citing.

To link to this article DOI: http://dx.doi.org/10.1057/s41293-021-00161-z

Publisher: Springer

All outputs in CentAUR are protected by Intellectual Property Rights law, including copyright law. Copyright and IPR is retained by the creators or other copyright holders. Terms and conditions for use of this material are defined in the End User Agreement.

\section{www.reading.ac.uk/centaur}

\section{CentAUR}

Central Archive at the University of Reading

Reading's research outputs online 


\title{
Enhancing Policy Delivery: Normalising Four Critical Contributions
}

\author{
Short title: Enhancing Policy Delivery
}

by

\author{
Andrew P. Kakabadse \\ University of Reading \\ Henley Business School \\ Greenlands \\ Henley-on-Thames \\ UK
}

and

\author{
Nada Kakabadse \\ University of Reading \\ Henley Business School \\ Greenlands \\ Henley-on-Thames \\ UK
}

\footnotetext{
Corresponding author

Prof. A. Kakabadse

University of Reading

Governance Group

Henley Business School

Greenlands

Henley-on-Thames

RG9 3AU

UK

a.kakabadse@henley.ac.uk
} 


\title{
ENHANCING POLICY DELIVERY: NORMALIZING FOUR CRITICAL CONTRIBUTIONS
}

\begin{abstract}
The desire to be more responsive to the demands of citizens complicates the relationship between Secretary of State and Permanent Secretary, and has an impact on policy delivery capacity. This article considers four separate contributions to effective policy delivery in a context of increasing and increasingly variegated demands: those provided by the Secretary of State, Permanent Secretary, special political adviser (SpAd) and chair of the departmental board. Drawing on insights garnered through a series of interviews with key policy actors, we draw attention to the SpAd bridging function between Secretary of State and Permanent Secretary, which eases the tension between ministerial urgency for outcomes versus the officials' realistic appraisal of 'smoothing out' the challenges to policy delivery. The departmental board's stewardship of policy delivery, meanwhile, is minimal due to the lack of chairmanship by the Secretary of State, requiring professional chairs to be appointed to this role.
\end{abstract}

Key words: Chair, departmental board, Permanent Secretary, policy delivery, Secretary of State, special political adviser (SpAd)

\section{Introduction}

Pressman and Wildavsky (1984: xxi-xxiii) define policy delivery as 'the process of interaction between the setting of goals and the actions undertaken to achieve them'. Thus, a wellfunctioning political-administrative interface is fundamental for effective public service delivery and through that, the realization of national goals (Kathyola, 2010). Therefore, the 
relationship between politician and official is considered as the 'fulcrum of Whitehall effectiveness' (HCPACAC, 2018: 1), as 'ministers and top public servants are politicaladministrators dependent on one another if they are to succeed' (Rhodes, 2016: 641).

The interaction between politician and civil servant is predicated on a delicate balance between political responsiveness and the duty of civil servants and ministers to respect legal and other normative constraints on executive authority (Christensen and Opstrup, 2018). Miller and McTavish (2009: 1) consider the political-administrative interface as 'the intersection of leadership roles within ... a tradition of a dichotomous relationship between political and administrative realms'. The Haldane Report (Ministry of Reconstruction, 1918) outlines the convention of indivisibility in the relationship between minister and civil servant, which rests on civil servants advising the minister, free from fear or favour, attracting high-calibre males and females, and positioning advisory bodies as valuable inputs for ministerial consideration. Manzie and Hartley (2013: 4) describe the minister's and Permanent Secretary's delicate, symbiotic, and often precarious interaction of working together as 'dancing on ice'. A professional, nonpartisan public service and a strong, core executive government is considered as fundamental to the Westminster system (Rhodes et al., 2009). Civil servants have been valued for 'party political neutrality', 'frank and fearless advice', 'integrity and propriety in the conduct of official business' and accepting 'the obligations of confidentiality, security and anonymity’ (Du Gay, 2009: 365).

The shift from a value base of 'public sector ethos' to New Public Management (NPM) driven by 'efficiency of competition and the market place' and then to New Public Governance (NPG) where value is 'dispersed and contested' (Osborne, 2010: 11) has challenged the relationship between Secretary of State and senior civil servants. The then Minister for the Cabinet Office, 
Francis Maude, argued that Permanent Secretaries had 'blocked' the implementation of government policy initiatives agreed by ministers (BBC News, 2012). Maude's proposed Reform Plan (HM Government, 2012) outlined how 'for too long operational management and delivery has been undervalued compared with policy development' and that the 'Civil Service will need to have greater operational experience and ability' (Cabinet Office, 2012: 16). The contrasting perspective is that of policy delivery depending 'not on the government itself, but on several different agencies and institutions, some in the public sector, others in the private sphere' (Wicks, 2012: 597). Two such noteworthy actors are special political advisers (SpAds) and the role and influence of departmental boards, particularly that of their chairs. It has already been noted that SpAds blur the separation of power between minister and public servant and that they need 'special handling' in order to contribute to effective policy delivery (Kathyola, 2010), which is considered as the most important component of the policy cycle (Bardach, 1977). Boards and their chairs are equally considered as critical to policy delivery as the very reason for their establishment was to oversee and advise on the compliance and stewardship of policy generation and delivery at the departmental level (Brown, 2005). Thus, we explore the Secretary of State, Permanent Secretary, SpAd, and chair/departmental board interaction in terms of contribution to the delivery of government policy.

This article focuses on the contribution and impact of four critical actors in the policy delivery process: Secretary of State, Permanent Secretary, SpAd, and chair/departmental board within the Westminster context. All four central actors in the policy delivery network are considered as interdependent with each other as they need the resources of the other actors to achieve their common goals (Börzel, 1998). 
In providing background to the study, the next section discusses the demands imposed on the Secretary of State, followed by an analysis of the role and contribution of the Permanent Secretary, SpAd, and chair/board. This is followed by an overview of the research findings on the influence of these actors on policy delivery. This article concludes with an assessment of the role, contribution, and impact of these actors, not only on each other but also cumulatively on the process of policy delivery, and makes recommendations on how interactions can be improved for efficacy gains.

\section{Policy Delivery}

Public policy has been conceptualized as the output from the political process shaping the political agenda, which in turn, acts as input impacting on subsequent policymaking (Pierson, 1993). In effect, public policies generate their own political durability by building extensive constituencies which, in turn, affect the preferences and capacities of elite actors such as interest groups, elected officials, and bureaucracies (Jones et al., 2019). Towards this end Hall and O'Toole (2000), view policy implementation as a battle to determine a correct reading of the mandate and its accurate execution.

Acknowledging that hierarchy is important in policy work, Rhodes (2007: 89) considers that 'it's the mix that matters' referring to the interaction between markets, hierarchy, and networks. Rhodes (1997: 9-10) also acknowledges that the UK 'policy networks privilege some interests, excludes others and are a form of 'private government'. Rhodes (1997: 203) argues from a resource-dependency perspective that the core executive displays 'fragmentation and coordination from actors ... So, they must exchange resources, for example money, legislative authority or expertise. These exchanges take the form of games in which actors seek to realise their objectives and manoeuvre for advantage.' 
In the study of managing boundaries between expertise and decisions, Cash et al. (2003) outlined three logics for scientific policy advisory functions, namely communication, translation, and mediation. Systems which have developed all three logics are viewed as more effective in balancing salience (relevance and timeliness of knowledge), credibility (scientific robustness of knowledge), and legitimacy (whether knowledge is produced in an unbiased way by considering relevant others) in the policy generated (Cash et al., 2003). Further, Veit et al. (2017) explored Cash et al's (2003) three logics at the institutional level, particularly in the German policy advisory system focusing on ministerial departments, research agencies, and governmental advisory bodies, with each pursuing their variant of institutional logic. In a similar vein Craft and Wilder (2017) identify four archetypes-policy content, purpose, issue, and relational policy ideational compatibility - to explain why and how policy advice varies both in content and influence.

Bearing in mind Cash et al's (2003) and Veit et al's (2017) perspectives, in this study, account is taken of the differing rationales towards policy delivery but at the individual role level of Secretary of State, Permanent Secretary, SpAd and chair of department board.

Certainly the difference between the expectations of policymakers and actual policy outcomes has been widely acknowledged (Pressman and Wildavsky, 1973; Sabatier, 1986; Cairney, 2009; Hill and Hupe, 2009). In the era of NPM, the focus was on the management of organizational resources and performance. However, in the era of NPG, the focus shifted to an emphasis on the negotiation of values, meanings, and relationships. The NPM period led to a proliferation of separate bodies and networks comprised of actors focusing on their specialized tasks, attempting to secure policy and service delivery through alternative agencies (Pollitt et 
al., 2007). These interconnections required coordination through an array of governance networks. The shift from traditional public administration (PA) to NPM to NPG is interpreted by some as a shift from a hands-on to a hands-off steering by the state (Osborne, 2010); in effect, "working with and through networks or webs of organisations to achieve shared policy objectives' (Rhodes, 2016: 64).

The UK's shift from corporatism and bureaucracy towards a more fragmented system of networks attracting many more policy participants (Jordan, 1981; Rhodes, 2016) has reshaped the policy environment. The new policy environment is seen as complex and potentially unstable, populated by 'many participants with different values, perceptions and preferences' (Sabatier, 2007: 3-4).

Traditionally, policy delivery was dependent on the quality of relationship between Secretary of State and Permanent Secretary. Now the pressure on both to deliver is considerable. The urgency to be seen to and to actually deliver policy through commitments made to constituents, the nation, and at the Despatch Box dominates the attention of the Secretary of State. In turn, the Permanent Secretary's concern is to effectively engage across often misaligned interests, but, with their ever-greater number, that takes more time. The two parties work according to different, often misaligned, timeframes when it comes to realizing policy outcomes. Hence the growing tension between urgency and realism leaves both parties exposed and vulnerable. The increasing complexity of interaction and resulting tension between Secretary of State and Permanent Secretary brings into question the role and contribution of SpAds and chair/departmental boards (Kakabadse and Kakabadse, 2020).

\section{Four Policy Delivery Actors}


Here we consider the roles and contributions of Secretary of State, Permanent Secretary, SpAds and chair/departmental boards.

\section{Secretary of State}

Secretaries of State are appointed as 'heads of departments and serve as the government's "bridgehead", connecting politics, public administration and civil society' (Andeweg, 2000: 377). Thus, Secretaries of State are central players in the core executive and have significant autonomy in the development and delivery of policy (Richards and Smith, 2002).

Although playing a crucial political role in the policy process, Secretaries of State are equally responsible for the leadership of their department (Andeweg, 2000), as they attend to new policy areas; 'build relationships within new departments; add value to the department's work; promote ideas to colleagues; and only then set about implementing them' (Cleary and Reeves, 2009: 1). In so doing, Secretaries of State are required to perform executive functions, determining how to effectively frame policy and enable its delivery across networks, departmental and other agencies, as well as consult with various interest groups (Börzel, 1998). In parallel, they steer policy through Cabinet and Parliament (Richards and Smith 2002; Kakabadse and Kakabadse, 2011) but all this is inhibited by short tenure, which between 2005 and 2010 averaged only 1.3 years (Cleary and Reeves, 2009).

\section{Permanent Secretary}

The Permanent Secretary (Permanent Under-Secretary of State) is the most senior civil servant leading a government department and is also the principal, non-political policy adviser, or 'neutral policy technician', to the minister (Ribbins and Sherratt, 2014). By statute, civil servants' 'accountability is to ministers who in turn are accountable to Parliament' (PASC, 
2012a: 12). Although the Secretary of State has the final say on policy decisions within her/his department, the reality is that the Permanent Secretary is deeply influential on matters of policy formulation and delivery, and can be perceived 'more generally as makers, resisters, shapers, sharers and takers of policy' (Ribbins and Sherratt, 2014: 32). To do so, Permanent Secretaries need to have the ability to manage the complexity of the ministerial/departmental interface and effectively act as a 'pivot point in balancing the needs and demands of ministers and high-level stakeholders within Whitehall and externally in the stewardship of their Department and its customers' (YCA, 2014: 6). Yet, despite their centrality in the policy process, their 'gatekeeping' function is eroded with ministers increasingly talking directly to civil servants (Page, 2006).

Irrespective of Permanent Secretary capability (Waller, 2014), the Cabinet Office (2012: 18) reported that much of policy 'failure has been because policy gets announced before implementation has been fully thought through'. In effect, the top-down, rationalistic model of policy delivery with emphasis on clear objectives, sound information management, and project management has received considerable criticism due to its implementation deficits (Pressman and Wildavsky, 1973; Sabatier, 1986; Rhodes, 2013). Additionally, ministerial short tenure is becoming increasingly matched by an increasing rate of churn at the top of the Civil Service. The average tenure in post for members of the Senior Civil Service is two years (HCPACAC, 2018). Under these circumstances, Rhodes (2013: 488) argues that 'civil servants are wary of speaking too much truth to power'.

\section{Special Political Advisers (SpAds)}

SpAds are appointed to serve an individual minister and recruited on political criteria at the minister's behest (Hustedt et al., 2017). Some see the rise of SpAds as the politicization of 
bureaucracy hiding behind their minister and exerting influence while escaping parliamentary control, thus blurring accountability arrangements within the Executive (Peters and Pierre, 2004; Eichbaum and Shaw, 2008). Others see their growing prominence as a response to the increasing complexity of policy creation and delivery, making them a necessary feature of contemporary government (Eichbaum and Shaw, 2011; Strömbäck, 2011). Some consider the growing prominence of SpAds as reflecting the Secretary of State's frustration with officials (Wicks, 2012). Although SpAds have existed in one form or another for centuries, it would be almost impossible for SpAds to operate effectively without the cooperation of civil servants (Talbot, 2014). Yet within the Westminster system, SpAds are not obliged by the provisions governing civil servant objectivity and political impartiality (Lodge et al., 2013; Eichbaum and Shaw, 2008). They are exempt from the civil servant requirement of appointment on merit (PASC, 2012b).

What is clear is that SpAds span multiple roles (Connaugton, 2015). On the one hand, SpAds play a beneficial role through protecting apolitical civil servants from partisan risks (Eichbaum and Shaw, 2010). Equally, they are also able to improve the quality of advice given to ministers by contesting the official's perspective or providing the political angle the civil servant cannot (Eichbaum and Shaw, 2008). Yet, SpAds have also sometimes exhibited an excès de zèle and there are many instances in which their actions have reportedly undermined the minister (Kenny, 2009). Overall, Grube (2015) argues that SpAds have become more influential than either senior civil servants or even ministers.

\section{Chair/departmental boards}

Since the 1990s, government departments have drawn on the advice of independent nonexecutive directors (NEDs) sitting on departmental boards. Typically, the Permanent Secretary 
acted as chair and the board included at least two independent NEDs (UK Parliament, 2018) 'largely drawn from the commercial, private sector' (CO and HMT, 2011; Cabinet Office, 2018: para 3.5), which was revised to four NEDs in 2011. The Ministerial Code (Cabinet Office, 2018: 7) revised that practice and stated that the Secretary of State should chair the departmental board and that 'the remit of the board should be performance and delivery and to provide strategic leadership to the department' (Kakabadse and Kakabadse, 2007).

Over time, however, departmental boards have come to be regarded as not very effective (UK Parliament, 2018). The reason why is because 'several departmental boards did not even meet the minimum threshold of four meetings a year' (UK Parliament, 2018: para 110), 'in large part due to the role of the Secretary of State as chair: where Secretaries of State do not take boards, or their role as chair, seriously, they deliver little value' (UK Parliament, 2018: para 110).

\section{The Study}

This study examines critical actors' experiences of policy delivery. It is based on 86 formal interviews with current and past Secretaries of State, ministers, Permanent Secretaries, senior

civil servants, SpAds, NEDs on departmental boards, and chairs and CEOs of arm's length bodies (ALBs) (Table 1). Access to this elite group was facilitated first through the support of the Public Administration and Constitutional Affairs Committee (PACAC) and then through the backing of the then Cabinet Secretary Lord Jeremy Heywood and also through the personal contacts of the authors. Anonymity was assured to all participants.

[Table 1 here] 
While in non-elite studies the inquirer more likely holds the position of expert, in elite studies those who are studied are 'in the know' (Mikecz, 2012: 483). Thus, although the interviewees needed the space to tell their stories, the inquirers needed to use critical judgement and probe deeper rather than taking stories at face value (Kakabadse and Louchart, 2012). The focus of the interview encounter was to 'understand the world from the study participants' perspective' and 'unfold the meaning of their lived world' (Kvale, 2006: 481), with particular focus on policy delivery. As the interviewees had busy schedules, often interrupted by political and operational priorities, the inquirers were flexible and often rescheduled the interview timetable.

The interviews ranged from 60 to 90 minutes, were audio-recorded when given permission to do so and subsequently transcribed. In the initial phase, thematic analysis was undertaken with each transcript with no a priori hypothesis. Thematic analysis is commonly used for encoding qualitative information to elucidate descriptive patterns (Boyatzis, 1998). Whilst data was analysed manually, software was used to identify 'codable moments' (Boyatzis, 1998). These codable moments were then assigned to either existing or newly created codes. The coding process was iterative, whereby codes were reviewed according to the patterns and themes that emerged. Table 2 summarizes the data structure outlining how we moved from empirical themes to conceptual categories and aggregate dimensions (i.e., themes) in the analytical process.

[Table 2 here]

\section{Analysis and Findings}


As highlighted in Table 2, thematic data analysis identified four key themes: policy delivery, role and contribution of SpAds, role and contribution of the chair/board, and the contribution and value of individual NEDs.

\section{Policy delivery}

Both Secretaries of State and senior civil servants concurred that, due to relentless pressure, the minister's orientation is, by nature, short-term, thus limiting the potential benefits to be gained from the policy process. Most interviewees commented that, in their experience, around 20 percent of their work is centred on policy creation, while 80 percent is devoted to ensuring effective and efficient policy delivery. Despite this, ministers are viewed by civil servants as overly concentrating on policy creation and not fully appreciating the reality of policy delivery. Certain ministers agreed with this point.

Many Secretaries of State do not recognize that the critical part of their job is the execution of policy. Many are in the old mindset of political thinking and public administration but that, from my experience, is only $20 \%$ of their job. The other $80 \%$ is making policy happen. (Secretary of State)

Senior civil servants agreed with the $20 / 80$ rule.

[I]f you then dig, which is the nature of what happens with politics, when you start going into the detail, most of the devil is in the detail... . (Permanent Secretary)

Other senior civil servants offered the view that greater consideration should be given to policy delivery challenges when first designing policy.

Once the policy's been set, we will then think about how we're going to deliver it, whereas actually you need to set deliverable policy. (Director General) 
An additional view was offered; that of civil servants becoming involved in policy development and delivery when writing the manifesto.

Quite a lot of what we're implementing is completely ridiculous, but we're doing it anyway because it's in the manifesto and that is because the people who wrote the manifesto didn't talk to anybody. They certainly didn't talk to anyone in the Department about what it would take to actually implement this thing and what the consequences would be if it were because they're there over there and we're over here. That's an extraordinary system, so fix that problem.... that would be a really significant change in which civil servants essentially would be working for Parliament rather than just for the minister. (Permanent Secretary)

Attending to policy delivery concerns at the point of designing the manifesto was also a concern. Some civil servants pointed to practices in other countries.

I would actually move us towards a system like they have in some other countries, like the Netherlands and I think in Finland and places where they actually cost manifesto commitments; you've really got to have a special office to do that. Because that would then enter into the public debate....now you tell me how much it's going to cost. (Permanent Secretary)

The emerging evidence indicates that the split between policy development, and delivery expertise and responsibility is artificial. This point has been appreciated for some time as studies from the 1960s argued that policy formation is about policy implementation (Bardach,1977; Mayntz, 1983). The fluid nature of policy creation blending into delivery challenges the rationalist perspective of separate processes (Hallsworth et al., 2011), referred to as the 
'implementation gap' and usually explored as a normative concern of ensuring that policies made by elected governments are carried out by subordinate authorities such as local governments and delivery agencies (Hill and Hupe, 2009). The study reported in this paper supports the perspective that policy formulation and delivery are inevitably the result of interactions among a plurality of separate actors with separate interests, goals and strategies' (Scharpf, 1978: 347).

\section{Role and contribution of the SpAd}

Most interviewees concurred that the critical factor determining the quality of policy delivery was the minister and that poor policy outcomes were down to "not thinking through the reality of making policy work' (Permanent Secretary).

For this reason, SpAds were viewed as having an important contribution to make.

Ministers' ideas on policy do not always easily translate into practice and that is always difficult to communicate to the minister. If this is not communicated sensitively to the minister, they will feel that they have been blocked. SpAds can help or hinder this conversation and in turn, deeply impact policy implementation. (Permanent Secretary)

The capability of and quality of contribution of SpAds also came under scrutiny. Some are really outstanding and were critical for making the Government work properly. Others ... they try and characterize the Department as being something which is stopping the Secretary of State achieve their intention. (Permanent Secretary) 
The more thoughtful SpAds were acknowledged as making a substantial contribution to policy delivery. In contrast, a considerable number of SpAds were viewed by officials as having a negative impact: 'All too many pursue their own agenda. Can be quite damaging,' said one (Chair, Departmental Board). The most damaging of SpAds were categorized as 'unthinkingly' driving through the minister's agenda: 'Just force through what the minister wants and the worst are the ones who do that unthinkingly' (Permanent Secretary).

Although some suggest that the SpAd's role is best understood in Machiavellian terms (Lord, 2004; McAlpine, 2000; Powell, 2010), others consider that the role can be useful to both the Secretary of State and the Permanent Secretary (Öhberg et al., 2017). In this study, effective SpAds were described as acting as the bridge between Permanent Secretary and Secretary of State, 'the first one to have a coffee with [the SpAd] to start the day' commented a Permanent Secretary.

Those SpAds identified as making a positive contribution were described as going beyond their advisory function and undertaking tasks such as brokering, networking, and even coordinating policy. Their positive contribution depended on their deep engagement with officials. Such SpAds were viewed as supportive and understanding of both sides. Their contribution was outlined as,

skirting around the Secretary of State through enhancing the minister's reputation whilst at the same time delivering on promises made knowing that these could take longer than publicly stated. (Permanent Secretary) 
For this to happen, a sound, positive working relationship between the Permanent Secretary and SpAd had evolved. Overall, the more supportive/bridging function orientated the SpAd, the more they were viewed as positively contributing to the delivery of policy.

\section{Role and contribution of chair/board}

UK government departmental boards have no legal role or status. Their effectiveness depends on the commitment, perceived contribution, and perspective adopted by each board member and especially on their perceived value by the Secretary of State. In turn, the value of a board depends on the attitude and behaviour of the very same Secretary of State in their role as chair (McNulty et al., 2011).

Studies repeatedly show that the chair is the most significant influence concerning board performance (Krause, 2017). On this basis, the minister's interest, attendance, and quality of chairmanship is likely to determine the value offered by the board. The participants in this study concurred with this view.

The effectiveness of the board seems to rely largely on the degree of seriousness with which the Secretary of State takes it. (Director General)

The departmental board very much depends on how ministers wish to use that departmental board. It acts much more as a, a sort of safeguard I guess for ministers to have others review whatever they choose to have reviewed in the way that the department operates. (Permanent Secretary)

The respondents acknowledge the potent influence of the chair under the Secretary of State. 
[T]here are some Secretaries of State who think they're really useful, and then, the board works. Others are not bothered about it, and the formal board meeting doesn't work. (Permanent Secretary)

Overall, most highlighted that boards offer little value due to the lack of interest and poor chairmanship displayed by the Secretary of State.

Yet, what was acknowledged was the potential of the board to contribute.

The policy space is underpinned by the net of complex relationships which need to work together. At the top there is the Secretary of the State, Permanent Secretary, SpAds, and the board, and when together down the line at the delivery level, intensity is even higher. (Permanent Secretary)

The comment offered referred to the minority of boards. Many reported that Secretaries of State are absent from consecutive board meetings. Of those Secretaries of State that attended as chairs, a considerable number focused only on their political agenda.

In our study, only two Secretaries of State behaved as evidence-driven chairs, focusing the board on the whole policy delivery process in order to offer advice, and to address blockages to policy delivery. Certainly, when the Secretary of State adopted the mantle of chair of the board, policy delivery was outlined as having improved through the emergent supportive interrelations facilitated by the chair, which enabled positive contributions from the civil servant and SpAd. 
Yet, despite the negative views expressed concerning boards and their contribution, particular NEDs were highly valued.

Non-executives, if they approach their role in a challenging but constructive way, can add enormous value to government, or government departments. (Permanent Secretary)

The experience, sense of independence, and constructive challenge brought by certain NEDs was viewed as valuable.

They bring independence and they bring experience. They often bring the experience of running an organization in the private sector especially to [this] arm's length body. (Permanent Secretary)

NEDs, from outside government, with extensive experience of overseeing large and complex organizations, were recognized as providing meaningful insights into the running of major projects and the management of the department. The NEDs' advisory contribution was due to the fact that they were not legally required to attend to matters of compliance. Their broader stewardship contribution of giving advice and challenging was seen to enable policy delivery. The contribution of NEDs was particularly valued by senior civil servants concerned with the oversight of ALBs. Certain departments work closely with ALBs for the delivery of their government priorities, including meeting spending targets.

I would say that, in my experience, what makes the difference to board effectiveness is the extent to which the Secretary of State and her ministers care about the views of non-executives. (Permanent Secretary) 
This finding is echoed by Hazell et al. (2018: 8) emphasizing that NEDs 'generally act as inhouse consultants'. Hazell et al. (2018) report that NEDs' expertise is not being used to its full potential due to certain ministers failing to understand the purpose of boards. In contrast, senior officials emerged as greatly valuing NEDs' advice and expertise. In support of Hazell et al. (2018), our study concludes that NED contribution is limited due to poor ministerial chairmanship but not poor-quality NED appointments. Even interviewees sceptical of the value of the departmental board were positive about the NEDs.

Their external viewpoint is very helpful in assisting us to improve the delivery of projects and services. (Secretary of State)

\section{Conclusion}

Our study results point to the need for four contributions to be made in order to enable effective policy delivery.

- Clarity of direction and purpose from the Secretary of State.

- Clear and sensitive analysis to be delivered from the civil servants concerning the nature of the challenges facing the policy and how to oversee them.

- The SpAds' conscious and sensitive balancing of the demands facing the Secretary of State to urgently deliver policy against the realistic appraisal by officials of how that policy can be delivered, which is unlikely to be within the timeframe expectation of the Secretary of State.

- The effective oversight of the policy delivery process by the departmental board through the chair's supportive engagement across numerous contrasting interests. However, the questionable chairmanship by the Secretary of State is identified as inhibiting the contribution from the departmental board. The emergent compensating factor is the positive influence of individual NEDs. 
These four contributions emerge as important to the delivery of policy due to the ever-evolving complexity of the policy landscape populated by an ever-increasing number of actors pursuing contrasting interests.

[I]t is a very relationship-based game as opposed to a structurally driven game and I don't think that's necessarily a bad thing. It's just, it is what it is. People therefore have to spend a lot of time developing their relationships, which probably feels a little bit frustrating for some. (NED, Departmental Board)

The ever-growing number of misalignments in the policy delivery process and their effects have been recognized for some time. The NPM as well as the NPG movements represented an attempt to correct the shortcomings of the traditional public organization in terms of service delivery (Kakabadse and Kakabadse, 2011). The NPM mantra was that government should 'steer', not 'row'. This resulted in the privatization of public sector entities paralleled by the introduction of market incentives (Pollitt and Bouckaert, 2017), which was accompanied by the greater usage of ministerial political advisers (Van den Berg, 2018). The minister-public servant dyad effectively morphed into a questionable, functioning triad (Shaw and Eichbaum, 2017). With NPG, the shift from hands-on to hands-off steering by the state encouraged working with and through networks or webs of interrelated organizations to achieve shared policy objectives. Interrelating through broader polycentric networks, including the spread of specialist consultants, lobbyists, and media has involved continuously re-negotiating and exchanging resources within agreed rules (Koliba et al., 2011). 
Underlying this exchange is the notion of engagement, whereby in the policy arena, Young et al. (2014) propose continually enhancing the capability for engagement amongst policy actors. Corporate governance studies offer supporting evidence of the positive impact of engagement, particularly when examining the critical influence of the chair of the board (Parker, 1990; Roberts, 2002). Emotional receptivity, or the ability to listen to at times unpalatable messages in order to realize policy alignment between different stakeholders is identified as a core contribution of the chair (Kakabadse et al., 2006). The study reported in this paper highlights the significant impact of the four focal roles in determining emotional receptivity for the purpose of enhancing policy delivery (Kakabadse et al., 2006).

An additional level of complexity lies in the fact that each policy area has its own set of actors (context) both within and outside the government (projects) who are interested in and participate in the policy lifecycle (Kearsley and Scheiderman, 1988). To address this complexity, since 2011, UK central government departments constituted the departmental board, chaired by the Secretary of State, as the governing body to oversee individual and departmental performance, risk management, talent development, and the scrutiny of major projects (Cabinet Office, 2017). Our study identifies this area as requiring the greatest attention in order to improve policy delivery, especially as budget constraints continue to put pressure on communities, forcing actors inside and outside of government to seek new policy solutions (Reich et al., 2017) but being hampered in doing so by questionable policy delivery practice.

For these reasons the dyad of Secretary of State and Permanent Secretary has extended to involve policy delivery inputs from SpAds and chairs/departmental boards. Our study concludes that attention needs to be given to two areas, the development of SpAds in order to better accommodate the tension between minister and official; and to the chair of departmental 
boards. However, little can be done to improve the performance and engagement capacity of departmental boards until the Secretary of State is replaced by a professional chair.

Overall, we conclude that the UK government is an effective administration, but inefficiently run. Better integration of the four inputs from Secretary of State, Permanent Secretary, SpAd, and departmental board will likely enhance engagement across stakeholders thus improving policy delivery capacity. Appropriately designed development for SpAds is viewed as a welcome investment in order to realize improved performance and contribution. But more drastic action is required to guarantee the more effective contribution of the departmental board to policy delivery. Providing for the development of chairs, on or off the job, is likely to make little impact. Leadership from the chair of the departmental board is missing. A consideration for the future is the possibility of the Secretary of State stepping down as chair of the departmental board and being substituted by an independently appointed, professional chair from the private or third sectors.

\section{References}

Andeweg, R.B. (2000) Ministers as double agents? The delegation process between Cabinet and Ministers. European Journal of Political Research 37(3): 377-95.

Bardach, E (1977), The Implementation Game: What Happens After a Bill Becomes a Law. Cambridge, MA: MIT Press.

BBC News. (2012) Civil servants blocking government policy unacceptable - Maude, 2 October, https://www.bbc.co.uk/news/uk-politics-19797736, accessed 10 May 2019.

Börzel, T.A. (1998) Organizing Babylon - on the different conceptions of policy networks. Public Administration 76(2): 253-73. 
Boyatzis, R.E. (1998) Transforming Qualitative Information: Thematic Analysis and Code Development. London: Sage.

Brown, W.A. (2005) Exploring the association between board and organizational performance in nonprofit organizations. Nonprofit Management and Leadership 15(3): 317-39.

Cabinet Office. (2012) The Civil Service Reform Plan, Cabinet Office and The Rt Hon Lord Maude of Horsham, http://www.civilservice.gov.uk/reform, accessed 20 July 2016.

Cabinet Office. (2017) Annual report and accounts. Assets Publishing Service, https://assets.publishing.service.gov.uk/government/uploads/system/uploads/attachment _data/file/646841/CO_Annual_Report_2016-17.pdf, accessed 17 April 2019.

Cabinet Office. (2018) Ministerial Code, https://assets.publishing.service.gov.uk/government/uploads/system/uploads/attachment _data/file/672633/2018-

0108_MINISTERIAL_CODE_JANUARY_2018__FINAL__3_.pdf, accessed 20 October 2019.

Cash, D.W., Clark, W.C., Alcock, F., Dickson, N.M., Eckley, N., Guston, D.H., Jaeger, J. and Mitchell, R.B. (2003) Knowledge systems for sustainable development. Proceedings of the National Academy of Sciences 100(14): 8086-8091.

Cairney, P. (2009) Implementation and the governance problem: a pressure participant perspective. Public Policy and Administration 24(4): 355-77.

Christensen, J.G. and Opstrup, N. (2018) Bureaucratic dilemmas: civil servants between political responsiveness and normative constraints. Governance 31(3): 481-98.

Cleary, H. and Reeves, R. (2009) The 'Culture of Churn' for UK Ministers and the Price We All Pay, Demos Research Briefing, 12 June 2009.

CO and HMT (Cabinet Office and HM Treasury). (2011) Corporate governance in central government departments: Code of good practice 2011, 
https://assets.publishing.service.gov.uk/government/uploads/system/uploads/attachment _data/file/220645/corporate_governance_good_practice_july2011.pdf, accessed 14 January 2021

Craft, J. and Wilder, M. (2017). Catching a second wave: Context and compatibility in advisory system dynamics. Policy Studies Journal 45(1): 215-39.

Du Gay, P. (2009) In defence of Mandarins: Recovering the 'core business' of public management. Management \& Organizational History 4(4): 359-84.

Eichbaum, C. and Shaw, R. (2008) Revisiting politicisation: Political advisers and public servants in Westminster systems. Governance 21(3): 337-63.

Eichbaum, C. and Shaw, R. (2010) Partisan Appointees and Public Servants: An International Analysis of the Role of the Political Adviser. Cheltenham: Edward Elgar.

Eichbaum, C. and Shaw, R. (2011) Political staff in executive government: Conceptualising and mapping roles within the core executive. Australian Journal of Political Science 46(4): 583-600.

Grube, D. (2015) Responsibility to be enthusiastic? Public servants and the public face of 'promiscuous partisanship'. Governance 28(3): 305-20.

Hazell, R., Cogbill, A., Owen, D., Webber, H. and Chebib, L. (2018) Critical friends? The role of non-executives on Whitehall Boards Constitution Unit 2, https://www.constitutionunit://publications/tabs/unitpublications/178_Critical_Friends_ The_Role_of_Non_Executives_on_Whitehall_Boards, accessed 10 May 2019,paras $4.43-4.44$.

HCPACAC (House of Commons, Public Administration and Constitutional Affairs Committee) (2018) The Minister and the Official: The Fulcrum of Whitehall Effectiveness, Fifth Report of Session 2017-19, HC 497, House of Commons. 
Hall, T. E. and O’Toole, Lawrence J. (2000) Structures for policy implementation: An analysis of national legislation, 1965-1966 and 1993-1994. Administration \& Society 31(6): $667-686$.

Hallsworth, M., Parker, S. and Rutter, J. (2011) Policy making in the real world, Institute for Government, https://www.instituteforgovernment.org.uk/sites/default/files/publications/Policy\%20m aking\%20in\%20the\%20real\%20world.pdf, accessed 29 December 2020.

Hill, M. and Hupe, P. (2009) Implementing Public Policy: Governance in Theory and in Practice. London: Sage.

HM Government (2012) Civil Service Reform Plan Published, https://www.gov.uk/government/news/civil-service-reform-plan-published, accessed 20 November 2019.

Hustedt, T., Kolltveit, K. and Salomonsen, H.H. (2017) Ministerial advisers in executive government: Out from the dark and into the limelight. Public Administration 95(2): 299311.

Jones, B.D., Theriault, S.M. and Whyman, M. (2019) The Great Broadening: How the Vast Expansion of the Policymaking Agenda Transformed American Politics. Chicago: University of Chicago Press.

Jordan, A.G. (1981) Iron triangles, woolly corporatism and elastic nets: Images of the policy process. Journal of Public Policy 1(1): 95-123.

Kakabadse, A. and Kakabadse, N. (2007) Leading the Board: The Six Disciplines of World. Basingstoke: Palgrave Macmillan.

Kakabadse, A.P. and Kakabadse, N.K. (2011) Eleven sides to the minister of the crown. British Politics 6(3): 345-78. 
Kakabadse, A and Kakabadse, N. (2020) SpAds: Political Sherpas Bridging Minister and Civil Servant. Open Journal of Political Science 10(2): 234-52.

Kakabadse, A., Kakabadse, N.K. and Barratt, R. 2006. Chairman and chief executive officer (CEO): That sacred and secret relationship. Journal of Management Development 25(3): 134-50.

Kakabadse, N.K. and Louchart, E.S. (2012) Delicate empiricism: An action learning approach to elite interviewing. In: A.P. Kakabadse and N.K. Kakabadse (eds.) Global Elites: The Opaque Nature of Transnational Policy Determination. Basingstoke: Palgrave Macmillan pp. 286-307.

Kathyola, J. (2010) The Political-administrative Interface, Commonwealth Good Governance, http://www.cpahq.org/CPAHQ/CMDownload.aspx?ContentKey=d9598edd-7340-4dfb8511, accessed on 10 November 2015, pp. 65-69.

Kearsley, G. and Shneiderman, B. (1998) Engagement theory: A framework for technologybased teaching and learning. Educational Technology 38 (5): 20-23.

Kenny, M. (2009) Taking the temperature of the British political elite 3: When grubby is the order of the day....'. Parliamentary Affairs 62(3): 503-13.

Koliba, C., Meek, J.W. and Zia, A. (2011) Governance Networks in Public Administration and Public Policy. Boca Raton, FL: CRC Press.

Krause, R. (2017) Being the CEO's boss: An examination of board chair orientations. Strategic Management Journal 38(3): 697-713.

Kvale, S. (2006) Dominance through interviews and dialogues. Qualitative Inquiry 12(3): 480500.

Lodge, G., Kalitowski, S., Pearce, N. and Muir, R. (2013) Accountability and responsiveness in the senior civil service: Lessons from overseas, 
https://www.civilservant.org.uk/library/2013_ippr_Accountability_and_Responsiveness _in_the_SCS.pdf, accessed 14 January 2021.

Lord, C. (2004) The Modern Prince. New Haven: Yale University Press.

LSE GV314 Group. (2012) New life at the top: Special advisers in British Government. Parliamentary Affairs 65(4): 715-32.

Manzie, S. and Hartley, J. (2013) Dancing on ice: Leadership with political astuteness by senior public servants in the UK, Open University Paper, The Open University Business School.

Mayntz, R. (1983) The conditions of effective public policy: A new challenge for policy analysis. Policy \& Politics 11(2): 123-43.

McAlpine, A. (2000) The Servant. London: Faber and Faber.

McNulty, T., Pettigrew, A., Jobome, G. and Morris, C. (2011) The role, power and influence of company chairs. Journal of Management \& Governance 15(1): 91-121.

Mikecz, R. (2012) Interviewing elites: Addressing methodological issues. Qualitative Inquiry 18(6): 482-93.

Miller, K.J. and McTavish, D. (2009) Leadership and the Political Administrative Change: Case of Scottish Local Authorities. Proceedings of the Political Association Annual Conference, 4-7 October 2009, Manchester, UK: Political Association.

Ministry of Reconstruction. (1918) Report of the Machinery of Government Committee, Civil Servant, http://www.civilservant.org.uk/library/1918_Haldane_Report.pdf, accessed 20 July 2016.

Öhberg, P., Munk Christiansen, P. and Niklasson, B. (2017) Administrative politicisation or contestability? How political advisers affect neutral competence in policy processes. Public Administration 95(1): 269-85.

Osborne, S.P. (2010) Introduction. The (new) public governance: A suitable case for treatment. In: S. Osborne (ed.) The New Public Governance: Emerging Perspectives on the Theory 
and Practice of Public Governance. London: Routledge and Taylor and Francis, pp. 116.

Page, E.C. (2006) How policy is really made. Public Management and Policy Association, London.

Parker, H. (1990) The company chairman: His role and responsibilities. Long Range Planning 23: $35-43$.

PASC (2012a) Special Advisers in the Thick of It, House of Commons Public Administration Select Committee, Sixth Report of Session 2012-13, HC 134, para.16, https://publications.parliament.uk/pa/cm201213/cmselect/cmpubadm/134/134.pdf, accessed 12 September 2019.

PASC (2012b) Change in Government: The Agenda for Leadership, Further Report with the Government Responses to the Committee's Eleventh, Thirteenth and Fifteenth Reports of Session 2010-12, $\quad$ HC https://publications.parliament.uk/pa/cm201012/cmselect/cmpubadm/1746/1746.pdf, accessed 15 October 2019.

Peters, B.G. and Pierre, J. (edds.) (2004) The Politicisation of the Civil Service in Comparative Perspective: The Quest for Control. London: Routledge.

Pierson, P. (1993) When effect becomes cause: Policy feedback and political change. World Politics 45(4): 595-628.

Pollitt, C. and Bouckaert, G. (2017) 'Public Management Reform: A Comparative AnalysisInto the Age of Austerity' (4th edn), Oxford: Oxford University Press.

Pollitt, C., Van Thiel, S. and Homburg, V. (2007) New Public Management in Europe. Basingstoke: Palgrave Macmillan.

Powell, J. (2010) The New Machiavelli. London: Bodley House. 
Pressman, J.L. and Wildavsky. A. (1973) Implementation. Berkeley-Los Angeles: University of California Press.

Reich, D., Shapiro, I. and Cho, C. (2017) Trump budget's deep cuts to block grants underscore danger of block-granting, Center on Budget and Policy Priorities, https://www.cbpp.org/sites/default/les/atoms/les/6-20-17bud.pdf, accessed 12 August 2019.

Rhodes. R. A. W. (1997) Understanding governance: Policy networks, governance, reflexivity and accountability. Buckingham: Open University Press.

Rhodes. R. A. W. (2007) Understanding governance: ten years on. Organization Studies 28: $1243-64$.

Rhodes, R.A.W. (2013) Political anthropology and civil service reform: Prospects and limits. Policy \& Politics 41(4): 481-96.

Rhodes, R.A. (2016) Recovering the craft of public administration. Public Administration Review 76(4): 638-47.

Rhodes, R.A.W., Wanna, J. and Weller, P. (2009) Comparing Westminster. Oxford: Oxford University Press.

Ribbins, P. and Sherratt, B. (2014) Reforming the Civil Service and revising the role of the Mandarin in Britain: A view from the perspective of a study of eight Permanent Secretaries at the Ministry of Education between 1976 and 2011. Public Policy and Administration 29(1): 21-44.

Richards, D. and Smith, M.J. (2002) Governance and Public Policy in the United Kingdom, (1st edn). Oxford: Oxford University Press.

Roberts, J. 2002. Building the complementary board. The work of the plc chairman. Long Range Planning 35: 493-520. 
Sabatier, P.A. (1986) Top-down and bottom-up approaches to implementation research: A critical analysis and suggested synthesis. Journal of Public Policy 6(1): 21-48.

Sabatier, P. (2007) The need for better theories. In: P. Sabatier (ed.) Theories of the Policy Process 2. Cambridge MA: Westview, pp. 3-20.

Scharpf, F.W. (1978) Interorganizational policy studies: Issues, concepts and perspectives. In: Hanf, K.I. and Scharpf, F.W. (eds) Interorganizational Policy Making: Limits to Coordination and Central Control. London: Sage, pp. 345-70.

Shaw, R. and Eichbaum, C. (2017) Politicians, political advisers and the vocabulary of public service bargains: Speaking in tongues? Public Administration 95(2): 312-26.

Shergold, P. (2010) Policy Implementation. Australian Government, Department of the Prime Minister and Cabinet, https://pmc.gov.au/government/policy-implementation, accessed 8 November 2017.

Strömbäck, J. (2011) Mediatization and perceptions of the media's political influence. Journalism Studies 12(4): 423-39.

Talbot, C. (2014) The British administrative elite: the art of changing without changing? Revue Française d'Administration Publique 151(2): 741-61.

UK Parliament. (2018) The minister and the official: The fulcrum of Whitehall effectiveness 5 departmental boards, UK Parliament, https://publications.parliament.uk/pa/cm201719/cmselect/cmpubadm/497/49708.htm, accessed 11 April 2019.

Van den Berg, C. (2018) The Netherlands: The emergence and encapsulation of ministerial advisers. In: R. Shaw and C. Eichbaum (eds.) Ministers, minders and mandarins: An international study of relationship at the executive summit of parliamentary democracies. Cheltenham: Edward Elgar Publishing, pp. 129-44. 
Veit, S., Hustedt, T. and Bach, T. (2017) Dynamics of change in internal policy advisory systems: The hybridisation of advisory capacities in Germany. Policy Science 50(1): 85103.

Waller, P. (2014) Special advisers and communications. In: B. Yong and R. Hazell (eds.) Special Advisers: Who They Are, What They Do and Why They Matter. London: Bloomsbury, pp. 87-109.

Wicks, M. (2012) What ministers do. The Political Quarterly 83(3): 585-98.

YCA. (2014) Indicators of potential for Permanent Secretary roles, BBC News, http://news.bbc.co.uk/1/shared/bsp/hi/pdfs/07_07_14_permanentsecretary.pdf, accessed 20 May 2019.

Young, J., Shaxson, L., Jones, H., Hearn, S., Datta, A. and Cassidy, C. (2014) ROMA: a guide to policy engagement and policy influence, ODI, https://www.odi.org/features/roma/whatis-roma, accessed 29 December 2020. 
Table 1: Study Participants

\begin{tabular}{|l|c|}
\hline \multicolumn{1}{|c|}{ Study participants } & Formal interviews \\
\hline Secretaries of State & 8 \\
\hline Ministers & 6 \\
\hline Permanent Secretaries & 17 \\
\hline Senior civil servants & 32 \\
\hline SpAds & 4 \\
\hline $\begin{array}{l}\text { NEDs on departmental } \\
\text { boards }\end{array}$ & 9 \\
\hline Chairs and CEOs of ALBs & 10 \\
\hline
\end{tabular}


Table 2: Coding Process

\begin{tabular}{|c|c|c|}
\hline Empirical Themes (examples) & $\begin{array}{l}\text { Conceptual } \\
\text { Categories }\end{array}$ & Themes \\
\hline $\begin{array}{l}\text { 'Ministers rightly attend to Parliament, party and their } \\
\text { constituents.' (Perm Sect) }\end{array}$ & \multirow[t]{2}{*}{$\begin{array}{l}\text { Overfocus on } \\
\text { policy creation }\end{array}$} & \multirow{4}{*}{ Policy delivery } \\
\hline $\begin{array}{l}\text { 'Surprisingly the } 20 / 80 \text { rule is still not appreciated, by the } \\
\text { ministerial team.' (Sec of State) }\end{array}$ & & \\
\hline $\begin{array}{l}\text { 'My Secretary of State becomes impatient when I explain the } \\
\text { numerous interests that need to be brought on board.' } \\
\text { (Director General) }\end{array}$ & \multirow[t]{2}{*}{$\begin{array}{l}\text { Underappreciation } \\
\text { of the reality of } \\
\text { policy delivery }\end{array}$} & \\
\hline $\begin{array}{l}\text { 'Having publicly made commitments, facing the reality of } \\
\text { policy implementation induces negativity in the minister.' } \\
\text { (Perm } \mathrm{Sec})\end{array}$ & & \\
\hline $\begin{array}{l}\text { 'My best friend is the SpAd acting as the bridge in } \\
\text { communication with the minister.' (Perm Sec) }\end{array}$ & \multirow{2}{*}{$\begin{array}{l}\text { SpAds vital } \\
\text { contribution to } \\
\text { policy delivery }\end{array}$} & \multirow{4}{*}{$\begin{array}{l}\text { Role and } \\
\text { contribution of } \\
\text { the SpAd }\end{array}$} \\
\hline $\begin{array}{l}\text { 'The SpAd is the meeting point between the minister's } \\
\text { agenda and the reality of making it happen.' (SpAd) }\end{array}$ & & \\
\hline $\begin{array}{l}\text { 'It is the unthinking SpAd pushing the minister's perspective } \\
\text { that causes most harm.' (Sec State) }\end{array}$ & \multirow{2}{*}{$\begin{array}{l}\text { Driving ministers' } \\
\text { agenda } \\
\text { irrespective of } \\
\text { context }\end{array}$} & \\
\hline $\begin{array}{l}\text { 'SpAds' only contribution is to make Minsters look good, } \\
\text { and for that reason, I will never have one.' (Sec of State) }\end{array}$ & & \\
\hline $\begin{array}{l}\text { 'I only go to certain board members because there is little } \\
\text { value in approaching the board as a whole.' (Perm Sec) }\end{array}$ & \multirow{2}{*}{$\begin{array}{l}\text { Unrealized } \\
\text { potential of } \\
\text { chair/board to } \\
\text { policy delivery }\end{array}$} & \multirow{4}{*}{$\begin{array}{l}\text { Role and } \\
\text { contribution of } \\
\text { chair/board }\end{array}$} \\
\hline $\begin{array}{l}\text { 'Under a different form of chair, the board could be so much } \\
\text { more.' (NED) }\end{array}$ & & \\
\hline $\begin{array}{l}\text { 'I think it was } 9 \text { months ago that I last met my chair who is } \\
\text { the Secretary of State.' (NED) }\end{array}$ & \multirow{2}{*}{$\begin{array}{l}\text { Poor } \\
\text { chairmanship } \\
\text { displayed by the } \\
\text { Secretary of State }\end{array}$} & \\
\hline $\begin{array}{l}\text { '... the Secretary of State uses the board meeting as a } \\
\text { political forum.' (NED) }\end{array}$ & & \\
\hline $\begin{array}{l}\text { 'When it's finance ... the experience of this NED is just } \\
\text { right.' (Perm Sec) }\end{array}$ & \multirow[t]{2}{*}{$\begin{array}{l}\text { High quality } \\
\text { individual }\end{array}$} & \multirow{2}{*}{$\begin{array}{l}\text { Contribution } \\
\text { and value of } \\
\text { individual } \\
\text { NEDs }\end{array}$} \\
\hline $\begin{array}{l}\text { 'Their [NEDs'] experience of other boards makes them an } \\
\text { invaluable asset.' (Director General) }\end{array}$ & & \\
\hline
\end{tabular}

